\title{
Article
}

\section{Challenges around automotive shredder residue production and disposal}

Khodier, Ala, Williams, Karl S and Dallison, Neil

Available at http://clok.uclan.ac.uk/18156/

Khodier, Ala, Williams, Karl S ORCID: 0000-0003-2250-3488 and Dallison, Neil (2018) Challenges around automotive shredder residue production and disposal. Waste Management, 73 . pp. 566-573. ISSN 0956-053X

It is advisable to refer to the publisher's version if you intend to cite from the work. http://dx.doi.org/10.1016/j.wasman.2017.05.008

For more information about UCLan's research in this area go to

http://www.uclan.ac.uk/researchgroups/ and search for <name of research Group>.

For information about Research generally at UCLan please go to http://www.uclan.ac.uk/research/

All outputs in CLoK are protected by Intellectual Property Rights law, including Copyright law. Copyright, IPR and Moral Rights for the works on this site are retained by the individual authors and/or other copyright owners. Terms and conditions for use of this material are defined in the policies page.

\section{CLoK}

Central Lancashire online Knowledge www.clok.uclan.ac.uk

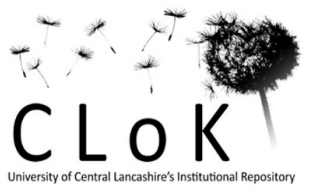




\title{
Challenges around automotive shredder residue production and disposal
}

\author{
Ala Khodier ${ }^{\mathrm{a}, *}$, Karl Williams ${ }^{\mathrm{a}}$, Neil Dallison ${ }^{\mathrm{b}}$ \\ ${ }^{a}$ Centre for Waste Management, University of Central Lancashire, Preston PR1 2HE, UK \\ ${ }^{\mathrm{b}}$ Recycling Lives Recycling Park, Preston, Lancashire PR2 5BX, UK
}

\section{A R T I C L E I N F O}

\section{Article history:}

Received 15 February 2017

Revised 20 April 2017

Accepted 4 May 2017

Available online $\mathrm{xxxx}$

\section{Keywords:}

Automotive shredder residue

End-of-life vehicle

Recycling

Recovery

Waste-to-energy

\begin{abstract}
A B S T R A C T
The challenge for the automotive industry is how to ensure they adopt the circular economy when it comes to the disposal of end-of-life vehicles (ELV). According to the European Commission the UK achieved a total reuse and recovery rate of $88 \%$. This is short of the revised ELV directive target of $95 \%$ materials recovery, which requires a minimum of $85 \%$ of materials to be recycled or reused. A significant component of the recycling process is the production of automotive shredder residue (ASR). This is currently landfilled across Europe. The additional $10 \%$ could be met by processing ASR through either waste-to-energy facilities or Post shredder technology (PST) to recover materials. The UK auto and recycling sectors claimed there would need to be a massive investment by their members in both new capacity and new technology for PST to recover additional recycle materials. It has been shown that $50 \%$ of the ASR contains valuable recoverable materials which could be used to meet the Directive target. It is expected in the next 5 years that technological innovation in car design will change the composition from easily recoverable metal to difficult polymers. This change in composition will impact on the current drive to integrate the European Circular Economy Package. A positive factor is that main driver for using ASR is coming from the metals recycling industry itself. They are looking to develop the infrastructure for energy generation from ASR and subsequent material recovery. This is driven by the economics of the process rather than meeting the Directive targets. The study undertaken has identified potential pathways and barriers for commercial thermal treatment of ASR. The results of ASR characterisation were used to assess commercial plants from around the world. Whilst there were many claiming that processing of ASR was possible none have so far shown both the technological capability and economic justification.
\end{abstract}

(c) 2017 Elsevier Ltd. All rights reserved.

\section{Introduction}

In the UK, there is an average of 2 million vehicles reaching the end of their life every year (Government UK nd). These end-of-life vehicles (ELV) end up at metal recovery facilities (either directly deposited or via a vehicle dismantler). In order to recover useful particular materials for recycling from these ELV depollution is necessary. It is a mandatory requirement that all ELVs are fully depolluted (e.g. all fluids, oil filters, batteries, catalytic converters, airbags removed) and component dismantled (e.g. tyres, windscreen) prior to the shredding processing. This is to reduce environmental pollution and recover certain streams separately. Dismantling is a step after depollution where vehicles reusable or recyclable component parts (e.g. tyres, windscreen, bumpers) are removed.

\footnotetext{
* Corresponding author.

E-mail addresses: akhodier@uclan.ac.uk (A. Khodier), kswilliams@uclan.ac.uk (K. Williams), neil.dallison@recyclinglives.com (N. Dallison).
}

Currently, the UK has 45 shredder sites dealing with end-of-life vehicles (BMRA Data, 2013). Each shredder site has a different layout but typically they will contain the following: a reception area; (where materials are received, inspected and validated); shredder plant and post-shredder processing/technologies. UK installations of shredders range from less than $746 \mathrm{~kW}$ up to $7457 \mathrm{~kW}$. The ELV Directive (EC, 2000) has set targets of $85 \%$ for the recovery of materials from vehicles. The new European ELV directive (European Parliament \& the European Council, Directive 2000/53/EC) (effected from January 2015) replaced the pervious target with a recycled or reused target of $95 \%$. Within this $95 \%$ the following apply: $85 \%$ must be recycled or reused and the remaining $10 \%$ can be met through energy recovery from the combustion of none-recyclable residues. Further, new EU legislation in progress by a circular economy (CE) package that ideally seeks for a zero waste framework (EPRS, 2016). The CE model is based on sharing, leasing, reuse, repair, refurbishment, recovery and waste into a valuable resource (including energy). The aim is for an almost closed loop, with special focus on urban and industrial waste, to achieve a better balance and harmony between economy, environment and society. For a typical 
vehicle from the early 2000s it will produce after shredding between 75 and $80 \%$ metals (GHK/BioIS, 2006; Cossu and Lai, 2015). It also produces smaller fraction of between 20 and $25 \%$ of the ELV's mass, which comprises non-metallic and lower density materials. TRL (2003) estimated that $1.8 \mathrm{Mt}$ of ELVs processed by UK shredders produced in a year 1.3 Mt of ferrous product (72\%), $72 \mathrm{kt}$ of non-ferrous product (4\%) and $430 \mathrm{kt}$ ASR shredder residue (24\%).

A separation based on density differences allows for separating the organic (plastics) and non-organic (metals \& glass) fraction in ASR. Typically, the ASR fraction contributes to between 15 and $20 \%$ of the initial ELV mass. It is expected that in the future as the composition of vehicles changes due to light weighting of materials and new material usage (polymer substitution for metal components), the amount of ASR will increase (Alonso et al., 2007; Hatzi-Hull, 2011; Davies, 2012). These changes to composition are not expected to offset the increase in vehicle weight due to safety features and increased comfort, which is being added by manufacturers. It is predicted in the next 5 years that technological innovation in car design will see the average weight per ELV from the current $900 \mathrm{~kg}$ to $1025 \mathrm{~kg}$ in 2020 . This increase in mass will be at the expense of easily recoverable metal with the introduction of engineering polymers. This change in composition will impact on the current drive to integrate the European Circular Economy Package. Automobiles are often cited as examples of closed loop products but clearly ASR being sent to landfill does not support this.

Another major change to vehicles has been the increase in electronic components units (ECU) and the corresponding presence of high value resources such as gold and rare earth metals (Restrepo et al., 2017). This will influence the recycling industry by changing the economics of processing ELVs. Several researchers (Cucchiella et al., 2016a,b; Cossu et al., 2014) have investigated the advantages of dismantling components prior to shredding. However, for ECUs to have value they need to be removed complete and this is not always practical. The compositional change of vehicles will influence the roles dismantler's and recyclers have in meeting the Directive targets (Inghels et al., 2016). The recycling sector still favours recycling over dismantling (Blume and Walther, 2013) and investment in PST would make more economic sense. The change to sustainable design for automotive products has the aim of encouraging dismantling of components (Tian and Chen, 2016). Since 2008 car manufacturers have been encouraged to make their vehicles easier to recover. However, this may not result in reuse of components as any damage of components will result in the component being shredding with the ELV. This then brings us back to the same situation that the ASR will need to processed to meet the targets and the valorisation of it PST (Fiore et al., 2012).

Recovery of rare earths from ASR and reduction of the hazardous of ASR will require thermal treatment. Sakai et al. (2014) illustrated that to meet the ELV targets ASR must be part of the recycling process. The challenge being how to recover the components in both a practical and economic manner. There are a number of high value components of ASR which could be recovered by thermal processing of ASR (Mayyas et al., 2016). The type of PST will be influences by the economics and ease of recovery of these products on a commercial scale (Cossu et al., 2014).

In order to meet the ELV Directive targets and maximize the recovery of material, post-shredder technologies (PST) will need to be employed. Studies have shown (Sakai et al., 2014) that different regions of the world place difference emphasis on recovery and the requirement to use dismantling of components to minimize ASR. This is dependent on legislation and targets. These technologies usually include mechanical separation plants and thermal recovery. The thermal treatment of ASR would alleviate some of the environmental concerns raised by Boughton and Horvath (2006). Other, solutions (Cossu and Lai, 2013) to remove leachate through PST of ASR does not offer a commercial solution and does not help to contribute towards the targets. The mechanical separation plants may or may not be attached directly to the shredder. The technologies used are: (i) magnetic separation for ferrous, (ii) eddy current magnets for non-ferrous, (iii) trommels, (iv) suction for foams and light material and (v) sink-float separation for plastics. Occasionally hand picking stations are employed to achieve the highest level of materials separation. The configuration of the mechanical separation/downstream processes is variable for companies, resulting in a variation on ASR compositions and production from one firm to another. Therefore, for ASR management, it is necessary to understand the ASR production process and to investigate its composition. Within the UK typically what is left after sorting is landfilled. Approximately, $40-50 \%$ of ASR is hydrocarbon-based: plastics, rubber, fibres, wood, paper, tar and oil. Thermal treatment of ASR reported either by pyrolysis (conversion to liquid), gasification (conversion to gaseous) or combustion (with heat recovery) technologies (Hubble et al., 1987; Zolezzi et al., 2004; Viganò et al., 2010; Cossu et al., 2014; Rey et al., 2016) will reduce the amount of material that requires final disposal. The ASR's noncombustible fraction which is made up of glass, dirt, rock, sand, moisture and residual metals can further separated and recycled.

Modelling of ELV recovery routes by several researchers (Fonseca et al., 2013; Gradin et al., 2013; Ciacci et al., 2010; Ruffino et al., 2014) concluded that energy recovery of ASR residue was a necessary part. This means that a combination of recycling and energy recovery is essential to achieve the new European ELV targets. The UK department for Business, Innovation and Skills (BIS) announced that an $88 \%$ reuse, recycling and recovery rate was achieved in 2012 meeting the previous target. However, UK Department for Environment, Food and Rural Affairs (Defra) and the, Environment Agency (and most recently British Metals Recycling Association (BMRA)) have published data which indicated that the levels of energy recovery from ASR are currently low. This is potentially an area where the UK could improve and meet the new targets. This is in contrast to the industry which is focused on reaching the higher target of $95 \%$ by applying PSTs based on mechanical separation rather than thermal treatment. This is due to the lack of any commercial off-the-shelf/small-scale solutions being available. Also, with no financial drivers to encourage investment in the necessary infrastructure to recover energy from ASR this option remains unused. The other challenge for any thermal exploitation of ASR is the amount of Polyvinyl chloride (PVC) plastics it contains. This produces acid gases which corrodes the boiler, gas duct and tubes of existing energy from waste facilities. Consequently, the preferred option for ASR has been to landfill. The heterogeneous and complex make-up means that it is difficult to separate with conventional sorting processes. Landfill disposal of ASR causes significant environmental problems (GHK/BioIS, 2006; Cossu and Lai, 2015) as it is used as daily landfill cover mixed with calcium carbonate (lime) to decrease leaching into ground water.

Due both to the changing ASR composition and its wide variability, the aim of this study is to characterise ASR produced from UK shredder plant and to identify post ASR management and treatment. The study has investigated the viability of post-shredder technologies (PST) using thermal treatment processing within the context of UK shredder plants.

\section{Material and methods}

\subsection{Production of ASR}

A shredder plant in the Northwest of the UK was used as a case study for ASR characterisation. The plant has a capacity of $416 \mathrm{kt}$ 
per year. The layout of the shredder plant is shown in Fig. 1. The plant consisted of: (1) a pre-shredder (where ELVs are processed after been depolluted); (2,3), conveyor system; (4), hammer mill; (5), magnetic drums (to separate ferrous and nonferrous materials); (6), quality material control of Z-box and cyclone system (where any remaining ferrous materials will be sent/removed through a Z-box section and any light fraction materials will be sent through the air cyclone separator), followed by (7) a conveyor system where shredded steels filtered and stored ready for export. The ASR is sized, stored and transported on conveyors to the postshredder technologies. This comprises of a series of mechanical metal separation processes over band magnets and eddy current separator and trommel screen. During the process two size fractions of $\leq 30 \mathrm{~mm}$ and $\leq 150 \mathrm{~mm}$ of ASR are produced.

Onsite monitoring of the facility was carried out over a threemonth period. The mass balance of ELVs entering the facility and the output from the shredding plant was recorded. The Duty of Care imposed on the organization ensured that all ELVs brought on to site were weighed and all paperwork (e.g. consignment notes) complied with the requirements of the Environment Agency. ELVs were depolluted and dismantled prior to shredding therefore all fluids and tyres were removed.

\subsection{Characterisation of ASR}

ASR composition was routinely analysed by the shredding company, in order to assess the plant efficiency, mass balance and any leachate environmental impacts. For the characterisation of ASR the $150 \mathrm{~mm}$ fraction produced by the plant was chosen. This fraction represents $75 \mathrm{wt} \%$ of the ASR produced from the process and has undergone post-shredder mechanical recovery of light metals and polymers. This fraction would go directly for energy recovery. All the analytical characterisation procedures applied British Standard methodology as detailed in the following paragraphs.

\subsubsection{Sampling procedure}

Characterisation of the ASR followed BS EN 14899 (2005) protocol. Samples were collected over a four-day sampling period to ensure a representative feedstock through the processing plant. For each day $52 \mathrm{t}$ of ASR was collected (total collected $208 \mathrm{t}$ of ASR). Each day's sample was cone and quartered following both BS EN 932-1 (1997) and CM3820 (2009) procedures. This procedure was chosen, as it is ideal for large amounts of material (Allen, 1981). This method initially starts with a heap (cone) of the material and is divided into 4 sections (quarters). The opposite quarters of the heap were rejected and the two remaining quarters were re-mixed and a smaller second heap formed. The process was then repeated until the required sample size was reached within one of the quarters. This produced a quartered sample of $200 \mathrm{~kg}$ per day. At the end of the four day period the accumulated daily samples were combined to produce an $800 \mathrm{~kg}$ sample. This sample was subsequently, crushed through a $50 \mathrm{~mm}$ screen using a Wagner Machienbau Gmbh Type WS30 $45 \mathrm{~kW}$ crusher. The crushed sample was subjected to coning and quartering procedures (BS EN 932-1 (1997) and CM3820 (2009)) to produce four $12.5 \mathrm{~kg}$ homogeneous sample (ASR1 - ASR4). Each samples was subjected to further grinding down using $30 \mathrm{k}$ in-line Muffin Monster. This produced samples of $<2 \mathrm{~mm}$. Samples were then extracted from this for characterisation analysis.

\subsubsection{Analytical methods}

A series of analytical techniques were used to determine the suitability of ASR for different thermal processes. The gross calorific value (CV) was determined by using a bomb calorimeter (BS EN 15400 (2011)). This determined the amount of energy available within the material for use in a thermal process. The moisture content was determined by drying samples in an oven at $80^{\circ} \mathrm{C}$ for a 12-h period (BS EN 15414 (2011)). The moisture has a large influence on the amount of energy available due to the high latent heat of water. The ash and volatile matter (VM) contents were determined from the percentage residues of the initial material which was combusted at $525^{\circ} \mathrm{C}\left( \pm 25^{\circ} \mathrm{C}\right.$, BS EN 15403 (2011)) and $925^{\circ} \mathrm{C}\left( \pm 25^{\circ} \mathrm{C}\right.$, BS EN $\left.15402(2011)\right)$, respectively. Fixed carbon (FC) was then calculated to give a total of 100 (\% by, weight) of the proximate analysis. Ultimate analysis of $\mathrm{S}, \mathrm{C}, \mathrm{H}, \mathrm{N}, \mathrm{Cl}$ were measured by absorption spectroscopy (method standard BS EN 15407 (2011) and BS EN 15408 (2011)). Trace elements of Hg, Cd, Ti, Sb, $\mathrm{As}, \mathrm{Cr}, \mathrm{Co}, \mathrm{Cu}, \mathrm{Pb}, \mathrm{Mn}, \mathrm{Ni}, \mathrm{Sn}, \mathrm{V}$, Se and $\mathrm{Zn}$ were analysed by inductively coupled plasma mass spectrometry (ICP-MS), method CEN/ TS 15411 (2006). The samples were prepared after nitric acid microwave digestion programmed for $0-200{ }^{\circ} \mathrm{C}$ (in $10 \mathrm{~min}$ ), held for $15 \mathrm{~min}$ and cooled down over a period of $35 \mathrm{~min}$.

\subsection{Commercial assessment of the thermal technologies}

A review was conducted of the thermal-processing plants available globally. Initially, all companies were included which had the potential to provide either biomass or waste thermal plants. These companies were subsequently evaluated to determine their potential suitability for use as an ASR thermal process technology provider. Initial screening of more than one hundred identified companies was carried out. This focused on the maturity of their
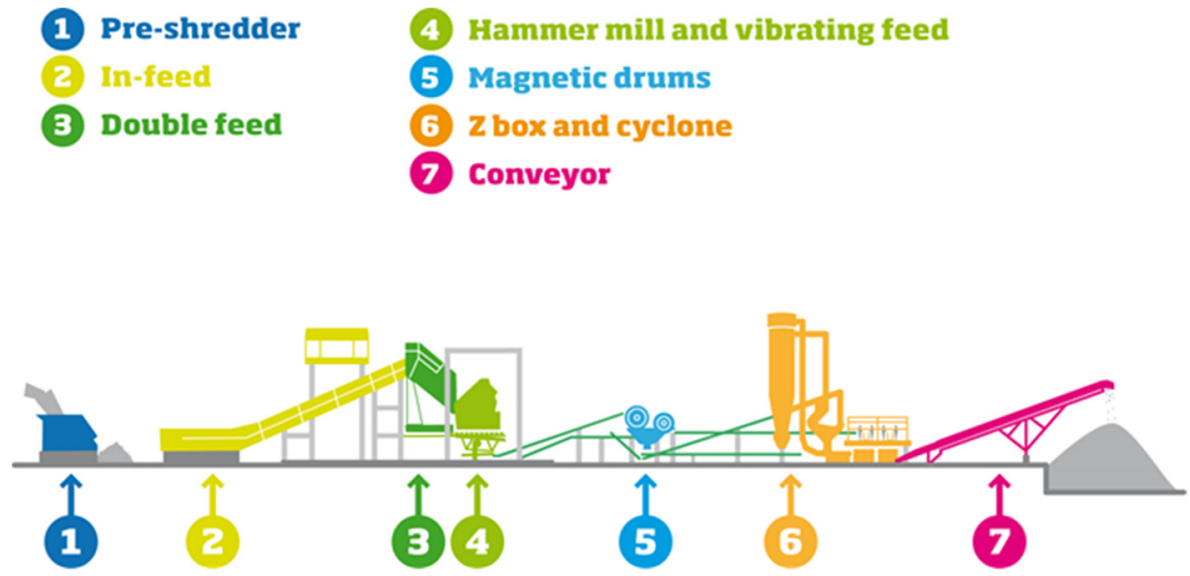

Fig. 1. Shredding plant layout of case study site. 
process and its suitability to utilise ASR. From this screening of the technology providers, 79 were selected and contacted in order to collect up-to-date information on the following: (i) services, (ii) products, (iii) technical and (iv) commercial maturity. The evaluation of these companies and their technology was based on the criteria listed in Table 1.

\section{Results and discussion}

Fig. 2 shows the mass balance of ELVs entering the site over study period. The amount of material recovered from the ELVs was $70 \%$ ferrous metals, 3\% non-ferrous metals and formation of 26\% ASR. Non-ferrous heavy materials were called Zorba, other materials produced; stainless steel, copper meatballs and wires. The results are below the ELV Directive targets which is a concern for the automotive industry which is required to meet these.

Table 1

List of criteria for shortlisting companies.

\begin{tabular}{ll}
\hline Criteria & Specifications, description \& conditions \\
\hline Waste type & - ASR \\
Purpose & - Pyrolysis and/or gasification process to convert ASR \\
& to an oil or gaseous fuel, which will be converted to \\
& electrical power \\
- & Supplier business nature (i.e. small to large \\
pechnology & corporation) \\
provider & Supplier capability such as warranties, potential of \\
& OEM (original equipment manufacturer) \\
Technology plant/ & - Experience of technology (e.g. number of units sold, \\
equipment & units in operation) \\
& - Materials pre-treatment (e.g. driers cost, screens) \\
- Reliability \& availability of the process & - Capital cost (supply \& installation) \\
Economic & - Operational costs ( $£ / M W_{\mathrm{e}}$ output) including \\
consideration & maintenance \\
& - Technical risk \\
Environmental & This includes emissions, quantities of residues, \\
impact & plant footprint and stack
\end{tabular}

However, these results are similar to other reported work (Morselli et al., 2010; Fiore et al., 2012). During the process two size fractions of $\leq 30 \mathrm{~mm}$ and $\leq 150 \mathrm{~mm}$ of ASR production were formed. ASR $\leq 150 \mathrm{~mm}$ size fraction represents $75 \%$ of the total ASR, with the $\leq 30 \mathrm{~mm}$ fraction making up the remaining $25 \%$. The plant produced $70 \mathrm{t}$ of ASR per day which required processing and final disposal to landfill. The current charge for landfilling ASR (September 2016) is $€ 114$ per tonne. Therefore, there is an opportunity to recover this material and meet both the ELV Directive and goals of the circular economy package.

Table 2 shows the result of ASR $150 \mathrm{~mm}$ material type compositions. It was possible to identify glass, plastics, textile, foam, rubber, wood, cork, wiring/electrical, paper, cardboard blended together and/or with soil and dust/dirt. The metal content was very low and was combined into the fines ( $<5 \mathrm{~mm}$ ) and difficult to separate. The mixed plastics accounted $47 \%$ by weight, whereas, the textile fraction was $11 \%$ by weight, (similar percentages reported by Mallampati et al., 2017 and Lin et al., 2010). Textiles together with polyurethane foam (PUF) and cork are derived from car seats and interior carpeting. The rubber contents, mostly from hoses, ranged from $8 \%$ to $23 \%$. The fines fraction was $7 \%$ by weight and supported Harder and Forton's (2007) study that this was difficult to break down into quantifiable materials.

The variability in particle size distribution for the $\leq 150 \mathrm{~mm}$ post additional shredding is shown in Table 3. It can be seen that $\geq 90 \%$ of the ASR was smaller than $30 \mathrm{~mm}$. This is in contrast to the larger size $40-50 \mathrm{~mm}$ representing < $1 \%$. However, size $30-40$ $\mathrm{mm}$ includes a large amount of PU foam which included embedded small fraction of plastics, glass and fines. The size distribution represents the mechanical properties of the different materials, with the brittle polymers ending up in the $\leq 30 \mathrm{~mm}$ fraction.

The characterisation of ASR in term of calorific value, proximate and ultimate compositions are presented Table 4 . The gross calorific value range from 16.3 to $23.4 \mathrm{MJ} / \mathrm{kg}$ expressed the variation on the sample compositions. This was due to sampling error resulting in more polymer rich samples than others. It is interesting to see that the copper content was low; this was mainly due to the post-shredder technologies removing copper. This particular ASR is therefore, better suited for energy recovery as it does not contain

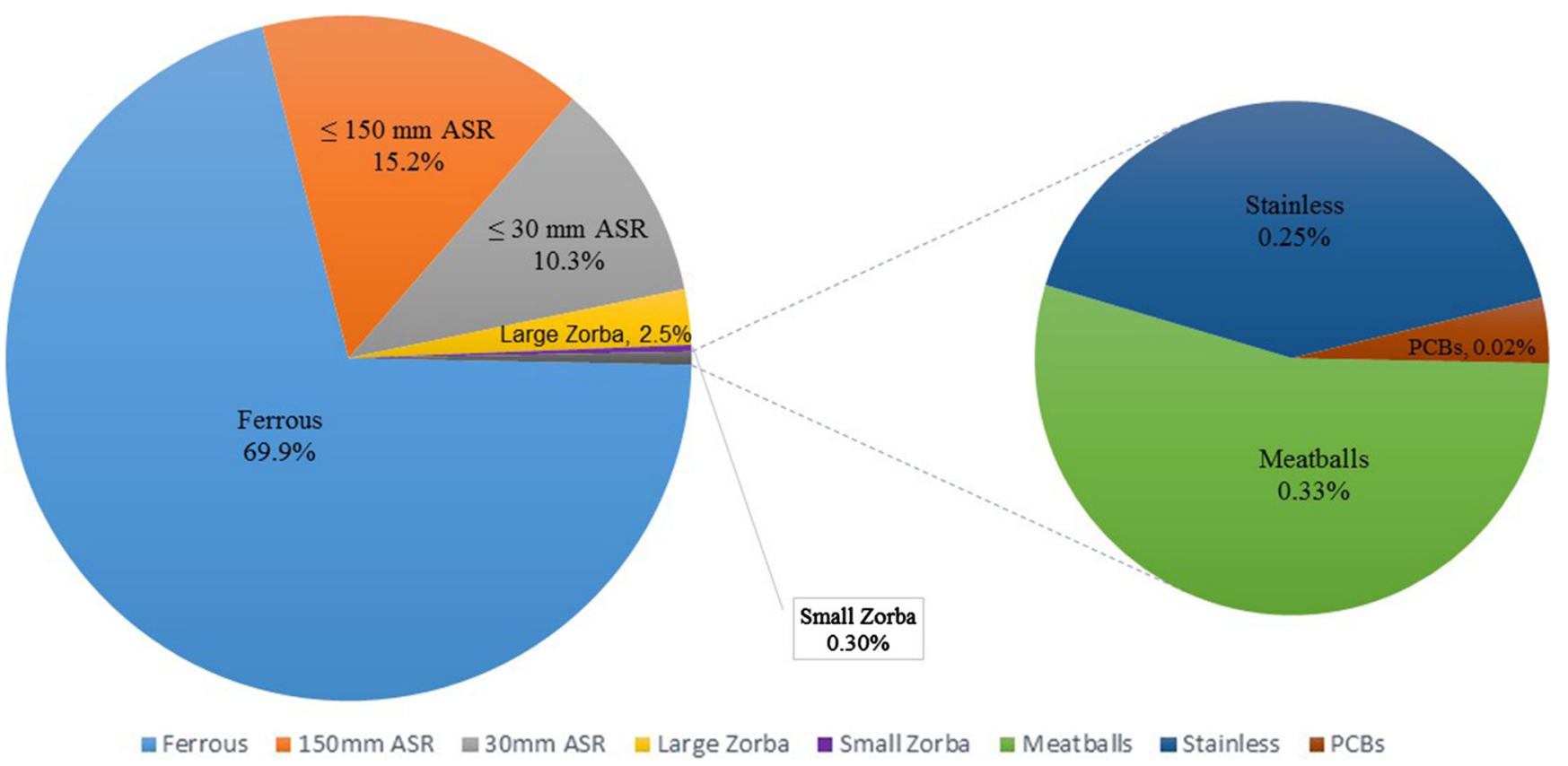

Fig. 2. Shredding plant mass balance. 
Table 2

Materials composition (\% of total mass) of the ASR quarter procedure.

\begin{tabular}{|c|c|c|c|c|}
\hline Materials (wt\%) & ASR 1 & ASR 2 & ASR 3 & ASR 4 \\
\hline Plastic & 47.88 & 45.21 & 51.67 & 42.97 \\
\hline Foam & 2.94 & 2.93 & 2.70 & 2.21 \\
\hline Rubber & 15.88 & 17.65 & 8.24 & 23.61 \\
\hline Textile/fabric & 10.35 & 8.65 & 12.23 & 10.61 \\
\hline Cork & 11.05 & 14.76 & 13.22 & 12.86 \\
\hline Wood & 1.17 & 1.34 & 0.64 & 1.53 \\
\hline Wiring/electrical & 1.76 & 2.10 & 1.76 & 0.14 \\
\hline Glass & 0.82 & 0.63 & 0.93 & 0.53 \\
\hline Paper & 0.47 & 0.31 & 0.38 & 0.26 \\
\hline Cardboard & 0.23 & 0.01 & 0.56 & 0.90 \\
\hline Dirt & 0.35 & 0.29 & 0.41 & 0.27 \\
\hline Fines (e.g. soil- not blended) & 6.57 & 5.00 & 6.01 & 3.02 \\
\hline Metals & 0.47 & 1.10 & 1.24 & 1.10 \\
\hline Others & 0.06 & 0.02 & 0.01 & 0.00 \\
\hline
\end{tabular}

* Keys: fine metals caught into a soil/dirt, hard to separate.

Table 3

ASR particle size distribution (subjected prior materials separation).

\begin{tabular}{ll}
\hline Size fraction & Result (\% weight) \\
\hline$<2 \mathrm{~mm}$ & $<1$ \\
$3-15 \mathrm{~mm}$ & 40 \\
$16-30 \mathrm{~mm}$ & 50 \\
$30-40 \mathrm{~mm}$ & 10 \\
$40-50 \mathrm{~mm}$ & $<1$ \\
$>50 \mathrm{~mm}$ & $<1$ \\
Total & 100 \\
\hline
\end{tabular}

Table 4

Characterisation of ASR, physical-chemical analysis.

\begin{tabular}{|c|c|c|}
\hline & Units & Results \\
\hline \multicolumn{3}{|l|}{ Calorific value } \\
\hline Gross calorific value & $\mathrm{kJ} / \mathrm{kg}$ & $16300-23500$ \\
\hline \multicolumn{3}{|l|}{ Proximate analysis } \\
\hline Moisture & wt\% & 22 \\
\hline Ash & wt\% & 20 \\
\hline Volatile matter & wt\% & 53 \\
\hline Fixed carbon & wt\% & 5 \\
\hline Total & wt\% & 100 \\
\hline \multicolumn{3}{|l|}{ Ultimate analysis (AR) } \\
\hline Carbon & wt\% & 28 \\
\hline Hydrogen & wt\% & 3 \\
\hline Nitrogen & wt\% & 2 \\
\hline Oxygen & wt\% & 14 \\
\hline Sulphur & wt\% & 0.2 \\
\hline Chlorine & wt\% & 0.3 \\
\hline \multicolumn{3}{|l|}{ Metals (AR) } \\
\hline Copper & $\mathrm{mg} / \mathrm{kg}$ & 7 \\
\hline Mercury & $\mathrm{mg} / \mathrm{kg}$ & $<1$ \\
\hline Cadmium & $\mathrm{mg} / \mathrm{kg}$ & $<1$ \\
\hline Thallium & $\mathrm{mg} / \mathrm{kg}$ & $<1$ \\
\hline Antimony & $\mathrm{mg} / \mathrm{kg}$ & 12 \\
\hline Arsenic & $\mathrm{mg} / \mathrm{kg}$ & $<1$ \\
\hline Chromium & $\mathrm{mg} / \mathrm{kg}$ & 16 \\
\hline Cobalt & $\mathrm{mg} / \mathrm{kg}$ & $<1$ \\
\hline Lead & $\mathrm{mg} / \mathrm{kg}$ & 56 \\
\hline Manganese & $\mathrm{mg} / \mathrm{kg}$ & 24 \\
\hline Nickel & $\mathrm{mg} / \mathrm{kg}$ & 7 \\
\hline Tin & $\mathrm{mg} / \mathrm{kg}$ & $<1$ \\
\hline Vanadium & $\mathrm{mg} / \mathrm{kg}$ & $<1$ \\
\hline
\end{tabular}

high levels of copper which acts as a catalyst for dioxin formation. Another added benefit of the composition is the low chlorine levels (related to the removal of electric cables) reducing the potential for dioxin formation further. The sulphur content of $0.20 \%$, by weight is similar to other studies reported (Mancini et al., 2010; Kameda et al., 2009; Saxena et al., 1995). The concentrations of some metals presented in this ASR such as $\mathrm{Ni}, \mathrm{Cu}, \mathrm{Hg}$ less than those reported previously (e.g. Mallampati et al., 2017). Other elements like C, $\mathrm{H}, \mathrm{O}, \mathrm{N}, \mathrm{Pb}, \mathrm{Mn}, \mathrm{Cr}, \mathrm{Tl}$ their concentrations within the range reported by Sakai et al. (2014) and Cossu et al., 2014 in their literatures reviewed of ASR properties.

Table 5 lists examples of worldwide companies which have or claim to have commercialised/marketed thermal treatment plants for pyrolysis or gasification. The study concentrated on commercial scale plants and as a consequence did not consider pyrolysis and gasification from universities, research institutions. From the review of companies and their technology selected number were identified as potential solutions to ASR disposal. The criteria for rejection were as follows:

- Feedstock that technology can use was not applicable - company unable to process ASR.

- Technology no longer promoted - either due to economic or technical problems.

Those that passed the initial sort were then evaluated against the criteria (shown in Table 1). A second round of evaluation was then undertaken looking at the economic methods of the process. Many organisations did not have robust economics for their process or lacked detail designs. This was reflected in there being limited documentation of operating thermal plants using ASR. Workers in this area (Vermeulen et al., 2011; Cossu and Lai, 2015) who have listed both experimental technologies and full scale applications concluded that research was required to prove the long-term prospect of thermal treatment of ASR. The organisations in Table 5 were sub-divided into the capacity of their plants. It can be seen that those plants between 10 and $1000 \mathrm{~kg} \mathrm{~h}^{-1}$ mostly used biomass material and were intended for small heat capacity applications. As the capacity size increased over $1000 \mathrm{~kg} \mathrm{~h}^{-1}$ the plants tended to use more plastic derived waste. This was closer to the composition of ASR and therefore would potentially offer a thermal processing solution.

The shredding industry finds itself having to make investments in un-proven technologies with limited economic data to justify such a move. In contrast those organisations with new thermal processes have yet to prove that ASR is a viable feedstock with many citing the variability of composition presenting challenges to their process. This support the view and the highlighted points of EPRS, 2016 that in practice moving towards a more circular economy would face a number of barriers and challenges. These would include financial (for businesses, in particular the cost of small and medium-sized enterprises); key economic enablers (lacking, inter alia, pricing systems encouraging efficient resource 
Table 5

Worldwide pyrolysis and gasification commercial companies.

\begin{tabular}{|c|c|c|c|}
\hline Company/plant owner & Country & Feedstock & Capacity (kg/h) \\
\hline 2G BioPOWER Ltd & UK & Tyres & nd (not disclosed) \\
\hline ANDRITZ Carbona & Finland & Wood & nd \\
\hline Babcock \& Wilcox Volund & Denmark & Wood, agricultural, RDF & nd \\
\hline Balboa Pacific Corporation & USA & Waste & nd \\
\hline BTG Biomass Technology Group & Netherlands & Biomass, waste & nd \\
\hline Future Blends Ltd & UK & Biomass & nd \\
\hline Radhe & India & Biomass & nd \\
\hline TK Energi AS & Denmark & Biomass & nd \\
\hline NREL & USA & Biomass & 10 \\
\hline VTT & Finland & Wood & 10 \\
\hline FCIPT & India & Medical waste & 20 \\
\hline RTI & Canada & Biomass (wood) & 20 \\
\hline TNO & Netherlands & Biomass & $10-30$ \\
\hline Bio-alternative & Switzerland & By-product oil & 50 \\
\hline GTRI & USA & Wood & 50 \\
\hline Pyrovac & Canada & Biomass (softwood bark) & 50 \\
\hline Daekung ESCO, Ltd & Korea & Oil palm EFB, pine, kelp & $41-83$ \\
\hline Metso-UPM & Finland & Biomass & 100 \\
\hline Union Fenosa & Spain & Wheat straw, pine, wood & 150 \\
\hline Agritherm & Canada & Sawdust, oil seed, bagsse & 200 \\
\hline Egemin & Belgium & Wood & 200 \\
\hline Renewable Oil Int. & USA & Biomass (various) & 200 \\
\hline Biomass Eng. Ltd & UK & Biomass (sawdust) & 250 \\
\hline C.A.R.E. Ltd & UK & Biomass, waste & $5-250$ \\
\hline PYTEC Thermochemische Anlagen GmbH & Germany & Wood, pine wood, wheat straw & 250 \\
\hline Ensyn & Canada & Agriculture & 400 \\
\hline GRES & Greece & Wood, sawdust, forest residues & 400 \\
\hline RESEM & Taiwan & Plastic (PE, PP, PS, ABS, Nylon) & $200-400$ \\
\hline Alten & Italy & Wood, agriculture & 500 \\
\hline FZK & Germany & Straw & 500 \\
\hline Lurgi LR & Germany & Biomass & 500 \\
\hline Wellman Process Eng. Ltd & UK & Wood chips & $250-500$ \\
\hline Anhui Yineng Bio-energy Ltd & China & Biomass, sewage sludge & 600 \\
\hline Beston & China & Mixed plastics & $250-800$ \\
\hline Shree Balaji Eng. Works & India & Waste plastics, tyres, wood & $250-800$ \\
\hline Cynar PLC & UK & Plastic (HDPE, LDPE, PP, PS) & $\sim 416,833$ \\
\hline ENEA & Italy & Biomass (wheat straw) & 1000 \\
\hline EPI Ltd & UK & Plastic, MSW, medical waste & 1000 \\
\hline Get Energy Prime & Italy & Plastics & $200-1000$ \\
\hline BTG & Netherlands & Palm (EFB) & 2000 \\
\hline Pyrocrat & India & Mixed plastics, carry bags, bottles & $125-2000$ \\
\hline ABRI-Tech INC. & Canada & Agriculture & 2083 \\
\hline CHO Power & France & Biomass, waste & 3000 \\
\hline Biogreen & France & Plastics, tyres, MSW, biomass & $\sim 3300$ \\
\hline VER GmbH & Germany & Biomass & 3500 \\
\hline Eqtec & Spain & Biomass, waste & 4000 \\
\hline Hudol Ltd & Wales, UK & Biomass, plastics & 4000 \\
\hline Vulcan & USA & Biomass, MSW, agriculture & 4000 \\
\hline HoSt & Netherlands & Biomass, waste, sludge & $1000-5000$ \\
\hline Dynamotive & Canada & Agriculture & 8000 \\
\hline Ebara & Japan & Plastics, biomass, sludge, MSW & 8125 \\
\hline Fortum & Finland & Wood, forest residues & 10000 \\
\hline Splainex & Netherlands & Plastics, biomass, tyres, MSW & Up to 21000 \\
\hline PRM Energy Systems Inc. & USA & Rice husk straw & $\sim 1250-83333$ \\
\hline Chinook Sciences & UK & MSW, biomass, RDF, industrial waste, yard waste & $\sim 4166666$ \\
\hline Anergy Ltd & UK & Waste, biomass & Pilot - Industrial \\
\hline Enerkum & Canada & Wood, peat, straw, MSW & Pilot - Industrial \\
\hline A.H.T. Pyrogas Vertriebs GmbH & Germany & Rice husks, wood & Industrial scale \\
\hline Feeco International & USA & Biomass, waste & Industrial scale \\
\hline Grubl Automatisierungstechik & Austria & Wood & Industrial scale \\
\hline \multicolumn{4}{|l|}{$\mathrm{GmbH}$} \\
\hline Klean Industries & Canada & Tyres, plastics, MSW, medical waste & Industrial scale \\
\hline Torftech Energy Ltd & UK & Food, biomass, waste, chemicals & Industrial scale \\
\hline
\end{tabular}

reuse and reflecting full environment costs); skills and multi-level governance (i.e. action required at many levels (e.g. international, European, national, local)). By utilising ASR as a potential fuel source and recovering metals and glasses which would normally be lost; there is an opportunity for the recycling sector to support the meeting of the ELV Directive.
In order to achieve ambitious policy targets settled by the ELV Directive on recycling, recovery and reuse, innovative integrated technologies need to be developed. Car makers should develop better end of use for manufactured products. Dismantling technologies and PST based on mechanical separation should concentrate on recovery techniques and address further utilisation of recoverable. 
However, an absence of clear design for dismantling (as stated in Cucchiella et al., 2016b) and lack information of PSTs mechanical separation. This study shows an ASR of high calorific value with low $\mathrm{Cl}$ and $\mathrm{Cu}$ contents. This may to efficient dismantling and PST applied. Also, the study presented the importance of PST using thermal treatment based on the amount of ASR daily production at a recycling industry (case studied). Yet challenges, no developers of new technologies worldwide were able commercially and technically proven the recovery of energy from ASR. Improvement of this work could be the assessment of car manufacturers current and future role in ELV recycling including ASR thermal treatment. As changes in the material composition of future vehicles (in particular electric cars) have a great impact on ASR properties, mid and long term measures are important.

\section{Conclusions}

The challenge of meeting the ELV Directive targets and the challenge of finding a better disposal route for (ASR), other than landfill is proving difficult for the recycling industry. The recycling industry is driven by economics and not targets and this is one of the critical barriers to adoption of new technology within the sector. Whilst the automotive industry has had targets imposed on them they have little control on the recycling of ELVs. Meeting the targets through the traditional processing of ELVs is becoming more difficult. This is due in part to the changing material composition adopted by car manufacturers. No longer can they rely on the bulk metal recycling to meet the target. There is a need for a paradigm shift to consider all the material produced from the recycling process if the higher recycling target of the ELV directive are to be met. The future implementation of the circular economy within the automotive industry has ignored the significant impact and role of ASR must play in achieving this end. This study has shown that the use of post-shredded technologies based on mechanical separation may not be enough to fulfil the EU target of 95\% of ELVs being recycled or reused. Research has shown that landfill is still the only feasible practical and economic option for ASR within the recycling industry. The composition and thermal properties of ASR does offer a potential solution. However, this is not without risk and it does present its own limitations when used for thermochemical processes such as pyrolysis or gasification. Currently, there are no commercial plants, which offer a feasible method for the thermal recovery of ASR. Worldwide there are a number of organisations which have processes, which are claimed can be adapted, but these are yet to be proven. Until alternative processes become viable it will be difficult to meet existing legislation without the recovery of ASR. Renewed efforts are necessary to employ alternative pathways for both the technology providers and shredding companies. Only then will a solution provide the access to the principles of the circular economy.

\section{Acknowledgement}

The authors gratefully acknowledge Innovate UK's financial support through the Knowledge Transfer Partnership (KTP). As well as the Recycling Lives Limited, Preston, UK for their financial support and access to their facility.

\section{References}

Allen, T., 1981. Particle Size Measurement. Chapman and Hall, London. Alonso, J.C., Doce, J., Fleischer, G., Geraghty, K., Greif, A., Rodrigo, J., Schmidt, W.P. 2007. Electrical and electronic components in the automotive sector: economic and environmental assessment. Int. J. Life Cycle Assess. 12 (5), 328-335.

Blume, T., Walther, M., 2013. The end of life vehicle ordinance in the German automotive industry - corporate sense making illustrated. J. Clean. Prod. 56, $29-38$
Boughton, B., Horvath, A., 2006. Environmental assessment of shredder residue management. Resour. Conserv. Recy. 47, 1-25.

BMRA, British Metals Recycling Association, 2013. BREF Style Report - Metal Fragmentising Operations. Industrial Emission Directive Project Ref: 71983. Mayer Environmental, Middlesex, UK.

BS, British Standards, 1997. BS EN 932-1: Tests for General Properties of Aggregates Part 1: Methods for Sampling. British Standard Institute.

BS, British Standards, 2005. BS EN 14899: Characterisation of Waste - Sampling of Waste Materials - Framework for the Preparation and Application of a Sampling Plan. British Standard Institute.

BS, British Standards, 2011a. BS EN 15400: Solid Recovered Fuels - Determination of Calorific Value. British Standard Institute.

BS, British Standards, 2011b. BS EN 15402: Solid Recovered Fuels - Determination of the Content of Volatile Matter. British Standard Institute.

BS, British Standards, 2011c. BS EN 15403: Solid Recovered Fuels - Determination of Ash Content. British Standard Institute.

BS, British Standards, 2011d. BS EN 15407: Solid Recovered Fuels - Methods for the Determination of Carbon (C), Hydrogen $(\mathrm{H})$ and Nitrogen $(\mathrm{N})$ Content. British Standard Institute.

BS, British Standards, 2011e. BS EN 15408: Solid Recovered Fuels - Methods for the Determination of Sulphur $(\mathrm{S})$, Chlorine $(\mathrm{Cl})$, Fluorine $(\mathrm{F})$ and Bromine $(\mathrm{Br})$ Content. British Standard Institute.

BS, British Standards, 2011f. BS EN 15414: Solid Recovered Fuels - Determination of Moisture Content Using the Oven Dry Method - Part 3: Moisture in General Analysis Sample. British Standard Institute.

CEN/TS, European Committee for Standardisation/Technical Specification, 2006 CEN/TS 15411: Solid Recovered Fuels - Methods for the Determination of the Content of Trace Elements (AS, Ba, Be, Cd, Co, Cr, Cu, Hg, Mo, Mn, Ni, Pb, Sb, Se, TI, $\mathrm{V}$ and $\mathrm{Zn}$ ). British Standard Institute (BSI).

Ciacci, L., Morselli, L., Passarini, F., Santini, A., Vassura, A., 2010. A comparison among different automotive shredder residue treatment processes. Int. J. Life Cycle Assess. 15, 896-906.

CM3820, 2009. Sampling https://www.chem.mtu.edu/chem_eng/faculty/kawatra/ CM3820_2009_Sampling.pdf (accessed 14.06.16).

Cossu, R., Fiore, S., Lai, T., Luciano, A., Mancini, G., Ruffino, B., Zanetti, M.C., 2014. Review of Italian experience on automotive shredder residue characterisation and management. Waste Manage. 34, 1752-1762.

Cossu, R., Lai, T., 2013. Washing treatment of automotive shredder residue (ASR). Waste Manage. 33, 1770-1775.

Cossu, R., Lai, T., 2015. Automotive shredder residue (ASR) management: an overview. Waste Manage. 45, 143-151.

Cucchiella, F., D’Adamo, I., Rosa, P., Terzi, S., 2016a. Automotive printed circuit boards recycling: an economic analysis. J. Clean. Prod. 121, 130-141.

Cucchiella, F. D’Adamo, I., Rosa, P., Terzi, S., 2016b. Scrap automotive electronics: a mini review of current management practices. Waste Manage. Res. 34 (1), 3-10.

Davies, G. 2012. Materials for Automobile Bodies. Elsevier Applied Science Publisher, Amsterdam.

EC, 2000. Directive 2000/53/EC of the European Parliament and the European Council of 18 September 2000 on End-of-Life Vehicles - Commission Statements. Off. J. Eur. Comm. L269, 0034-0043, Brussels.

EPRS, 2016. European Parliamentary Research Service. Closing the loop: new circular economy package. <www.europarl.europa.eu/RegData/etudes/BRIE/ 2016/573899/EPRS_BRI(2016)573899_EN.pdf (accessed: 11.08.16).

Fiore, S., Ruffino, B., Zanetti, M.C., 2012. Automobile shredder residues in Italy: characterisation and valorisation opportunities. Waste Manage. 32 (8), 15481559.

Fonseca, A.S., Nunes, M.I., Matos, M.A., Gomes, A.P., 2013. Environmental impacts of end-of-life vehicles management: recovery versus elimination. Int. J. Life Cycle Assess. 18 (7), 1374-1385.

GHK/Biols, 2006. A study to Examine the Benefits of the End of Live Vehicles Directive and the Costs and Benefits of a Revision of the 2015 Targets for Recycling, re-use and Recovery Under the ELV Directive - Final Report to DG Environment J2232, Birmingham, UK https://ec.europa.eu/environment/waste/ pdf/study/final_report.pdf (accessed 14.08.16).

Government UK, nd. Environmental management - guidance. <https://www.gov. uk/guidance/end-of-life-vehicles-elvs-guidance-for-waste-sites> (accessed: 25.08.16).

Gradin, K.T., Luttropp, C., Björklund, A., 2013. Investigating improved vehicle dismantling and fragmentation technology. J. Clean. Prod. 54, 23-29.

Harder, M.K., Forton, O.T., 2007. A critical review of developments in the pyrolysis of automotive shredder residues. J. Anal. Appl. Pyrol. 79 (1), 387-394.

Hatzi-Hull, A., 2011. Green Economy: 10 Year of Success Story of End Life Vehicles. Ecomondo Congress, Rimini.

Hubble, W.S., Most, I.G., Wolman, M.R., 1987. Investigation of the Energy Value of Automobile Shredder Residue. U.S. Department of Energy Report DOC/ID12551, Washington, D.C.

Inghels, D., Dullaert, W., Raa, B., Walther, G., 2016. Influence of composition, amount and life span of passenger cars on end of life vehicles waste in Belgium: a system dynamics approach. Transport. Res. A - Pol. 91, 80-104.

Kameda, T., Fukuda, Y., Park, K.-S., Grause, G., Yoshioka, T., 2009. Efficient dehalogenation of automobile shredder residue in $\mathrm{NaOH} /$ ethylene glycol using a ball mill. Chemosphere 47, 287-292.

Lin, K.-S., Chowdhury, S., Wang, Z.-P., 2010. Catalytic gasification of automotive shredder residues with hydrogen generation. J. Power Sour. 195 (18), 6016-6023. 
Mallampati, S.R., Lee, B.H., Mitoma, Y., Simion, C., 2017. Selective sequential separation of ABS/HIPS and PVC from automobile and electronic waste shredder residue by hybrid nano-Fe/ $\mathrm{Ca} / \mathrm{CaO}$ assisted ozonisation process. Waste Manage. 60, 428-438.

Mancini, R., Tamma, P., Viotti, P., 2010. Thermal process of fluff: preliminary tests on a full scale treatment plant. Waste Manage. 30 (8-9), 1670-1682.

Mayyas, M., Pahlevani, F., Handoko, W., Sahajwalla, V., 2016. Preliminary investigation on the thermal conversion of automotive shredder residue into value-added products: graphitic carbon and nano-ceramics. Waste Manage. 50, $173-183$.

Morselli, L., Santini, A., Passarini, F., Vassura, I., 2010. Automotive shredder residue (ASR) characterisation for a valuable management. Waste Manage. 30 (11), 2228-2234.

Restrepo, E., Løvik, A.N., Wäger, P., Widmer, R., Lonka, R., Müller, D.B., 2017. Stocks, flows and distribution of critical metals in embedded electronics in passenger vehicles. Environ. Sci. Technol. 51 (3), 1129-1139.

Rey, L., Conesa, J.A., Aracil, I., Garrido, M.A., Ortuño, N., 2016. Pollutant formation in the pyrolysis and combustion of automotive shredder residue. Waste Manage. 56, 376-383.

Ruffino, B., Fiore, S., Zanetti, M.C., 2014. Strategies for the enhancement of automobil shredder residues (ASRs) recycling: results and cost assessment. Waste Manage. 34 (1), 148-155.
Sakai, S., Yoshida, H., Hiratsuka, J., Vandecasteele, C., Kohlmeyer, R., Rotter, V.S. Passarini, F., Santini, A., Peeler, M., Li, J., Oh, G., Chi, N.K., Bastian, L., Moore, S. Kajiwara, N., Takigami, H., Itai, T., Takahashi, S., Tanabe, S., Tomoda, K., Hirakawa, T., Hirai, Y., Asari, M., Yano, J., 2014. An international comparative study of end of life vehicle (ELV) recycling systems. J. Mater. Cycles Waste Manage. 16, 1-20.

Saxena, S.C., Rao, N.S., Rehmat, A., Mensinger, M.C., 1995. Combustion and cocombustion of auto fluff. Energy 20, 877-887.

Tian, J., Chen, M., 2016. Assessing the economics of processing end of life vehicles through manual dismantling. Waste Manage. 56, 384-395.

TRL Ltd, 2003. Data required to monitor compliance with end of life vehicle directive. Report for Defra, UK. <https://www.defra.gov.uk/environment/ waste/topics/elvehicles/trlstudy-one.pdf> (accessed: 18.08.16).

Vermeulen, I., Van Caneghem, J., Block, C., Baeyens, J., Vandecasteele, C., 2011. Automotive shredder residue (ASR): reviewing its production from end-of-life vehicles (ELVs) and its recycling, energy or chemicals valorization. J. Hazard. Mater. 190 (1), 8-27.

Viganò, F., Consonmi, S., Grosso, M., Rigamonti, L., 2010. Material and energy recovery from automotive shredder residue (ASR) via sequential gasification and combustion. Waste Manage. 30 (1), 145-153.

Zolezzi, M., Nicolella, C., Ferrara, S., Iacobucci, C., Rovatti, M., 2004. Conventional and fast pyrolysis of automobile shredder residue (ASR). Waste Manage. 24 (7), 691-699. 